\title{
Komponen Cadangan sebagai Wujud Bela Negara dan Strategi dalam Menangkal Ancaman Radikalisme-Terorisme di Indonesia
}

\author{
Yesika Theresia Sinaga \\ Pusat Studi Damai dan Resolusi Konflik Universitas Pertahanan Republik Indonesia \\ sinagayesika95@gmail.com
}

\begin{abstract}
ABSTRAK
Urgensi pembentukan Komponen Cadangan kerap menuai pro dan kontra di kalangan masyarakat. Adapun demikian, program ini merupakan realisasi amanah Undang-undang tentang Pengelolaan Sumber Daya Nasional untuk Pertahanan Negara. Selain ancaman perang dan bencana alam, salah satu ancaman adalah radikalisme-terorisme hingga penyebaran ideologi anti Pancasila. Penelitian ini bertujuan untuk menawarkan program pendampingan khususnya dalam urgensi ancaman saat ini. Tulisan ini menggunakan metode pendekatan kualitatif yang sumber data diperoleh dari kajian pustaka. Hasil penelitian ini adalah bahwa selain kemampuan dasar militer, dalam mengatasi ancaman nonmiliter seperti yang dibahas dalam tulisan ini, diperlukan pendampingan dan pemahaman mengenai Pancasila, wawasan kebangsaan, kondisi aktual Indonesia, untuk dapat memahami masalah dan mencari jalan keluar. Sebagai individu yang berperan sebagai anggota Komponen Cadangan yang akan dikembalikan ke lingkungan masyarakat sesuai pekerjaannya, diharapkan mampu menjadi agen perdamaian yang mencitrakan nilai bela negara dan Pancasila. Oleh karena itu, tulisan ini diharapkan mampu memberi masukan kepada program pendampingan dan pendidikan Komponen Cadangan yang berasal dari generasi muda Indonesia agar mampu menjadi sosok yang inspiratif, kreatif, dan inovatif dalam menjaga nilai-nilai Pancasila di tengah kondisi global saat ini.
\end{abstract}

Kata kunci : komponen cadangan, bela negara, Pancasila, radikalisme

\begin{abstract}
The urgency of forming Reserve Components often brings pros and cons among the public. Meanwhile, this program is a realization of the Law on the National Resources Management for National Defense. In addition to the threat of war and natural disasters, one of the threats nowadays is radicalism-terrorism to the spread of anti-Pancasila ideology. This study aims to offer a mentoring program, especially in the urgency of the current threat. This paper uses a qualitative approach where the data source is obtained from a literature review. The results of this study are that in addition to basic military capabilities, in overcoming non-military threats, assistance and understanding are needed about Pancasila, the actual condition of Indonesia, and national insight, to be able to find solutions. As an individual who acts as a member of the Reserve Component who will be returned to the society, he or she is expected to be an agent of peace who potrays the values of defending the country and Pancasila. Therefore, this paper is expected to be able to provide input in mentoring and education program of Reserve Component. Furthermore, Indonesia young people who are members of Reserve Component shall be inspirational, creative, and innovative figures in maintaining the values of Pancasila in the midst of today's global conditions.
\end{abstract}

Keywords : reserve component, state defense, Pancasila, radicalism 


\section{PENDAHULUAN}

Mempertahankan negara adalah kewajiban seluruh warga Negara Indonesia. Pertahanan rakyat semesta menjadi kekuatan dan karakteristik Bangsa Indonesia dalam menghadapi ancaman dan perubahan lingkungan strategis. Dikutip dari Doktrin Pertahanan Negara (2014), "Sistem pertahanan negara adalah sistem pertahanan yang bersifat semesta yang melibatkan seluruh warga negara, wilayah, dan sumber daya nasional lainnya, serta dipersiapkan secara dini oleh pemerintah dan diselenggarakan secara total, terpadu, terarah, dan berlanjut untuk menegakkan kedaulatan negara, keutuhan wilayah, dan keselamatan segenap bangsa dari segala ancaman."

Kesemestaan sebagai satu strategi warisan perjuangan kemerdekaan Bangsa Indonesia oleh para pejuang seperti taktik perang Gerilya diharapkan tetap mampu lestari dan actual penerapannya. Tidak dimaknai sebagai perang konvensional, tetapi perlu disadari bahwa ancaman untuk keamanan negara semakin luas lingkup dan jenisnya.

Radikalisme terorisme menjadi salah satu ancaman nir-militer yang dalam sepuluh tahun terakhir menjadi salah satu tugas berat dalam upaya penanggulangannya. Ancaman nonmiliter dapat berdimensi ideologi, politik, ekonomi, sosial, informasi, teknologi, dan keselamatan umum (Doktrin Pertahanan Negara, 2014). Sasaran ancaman terhadap pertahanan negara dilaksanakan untuk menjaga dan melindungi kedaulatan negara, keutuhan wilayah NKRI dan keselamatan segenap bangsa (Doktrin Pertahanan Negara, 2014). Masuknya ideologi anti-Pancasila merupakan salah satu indikator bahwa radikalisme terorisme harus menjadi fokus utama dalam program dan kebijakan pertahanan dan keamanan negara.

Khususnya di kalangan orang muda dengan kebutuhan dan kondisi saat ini yang memungkinkan untuk seluruh informasi dapat diakses. Tidak ada tembok pembatas atau filtrasi yang nyata dalam arus informasi salah satunya penyebaran ajakan untuk menerima ideologi baru.

Salah satu kebijakan pemerintah khususnya dalam lingkup pertahanan negara adalah membentuk Komponen Cadangan yang berasal dari perekrutan masyarakat sipil. Pengorganisasian Komponen Cadangan, disesuaikan dengan sifatnya sebagai komponen untuk memperkuat dan memperbesar Komponen Utama dan pembinaannya disesuaikan dengan organisasi dan pembinaan TNI yang terdiri atas Angkatan Darat, Laut, dan Udara dengan kekhasan masing-masing (Doktrin Pertahanan Negara, 2014).

Pembentukan Komponen Cadangan menjadi satu hal yang urgensi. Terutama saat ini di mana kondisi pandemik yang masih belum diatasi dengan baik, masyarakat banyak memberi opini mengenai tidak ada urgensi program Komponen Cadangan dan anggarannya sebaiknya dialokasikan ke penanggulangan Pandemi Covid-19. Dikutip dari media daring mediaindonesia.com dituliskan bahwa urgensi Komcad, Kemenhan perlu diperjelas. Diperkuat lagi dengan pernyataan dari Pengamat Hubungan Internasional Universitas Katolik Parahyangan Vrameswati Omega Wati kepada Media Indonesia bahwa perlu diperjelas urgensi pembentukan Komcad terutama proyeksi ancaman ke depan yang dihadapi oleh Indonesia. Komcad harus dipastikan sesuai dengan potensi tantangan ancaman kedaulatan.

Meskipun pro dan kontra mengenai urgensi pembentukan Komponen Cadangan masih ada di tengah masyarakat, merujuk kepada Doktrin Pertahanan Negara bahwa Pertahanan Rakyat Semesta harus diimplementasikan lebih modern dan terorganisir menyesuaikan perkembangan zaman dan kebutuhan lingkungan strategis salah satunya pembentukan Komponen Cadangan (Komcad) sebagai implementasinya (Kementrian Pertahanan, (tanpa tahun), diakses dari ppid.kemhan.go.id).

Di dalam doktrin pertahanan (Buku Doktrin Pertahanan Negara) dijelaskan bahwa Kebijakan pertahanan negara memiliki dua dimensi yang merupakan kesatuan yang tak terpisahkan yakni pertahanan militer dan pertahanan nonmiliter. Selain itu sebagai fungsi dan peran militer terbagi menjadi dua yakni melakukan Operasi Militer Selain Perang (OMSP) dan Operasi Militer Perang (OMP). 
Di saat kita melihat anggota militer yang ikut serta dalam kegiatan kebencanaan misalnya, saat itu militer bertugas dalam operasi militer selain perang. Banyaknya kegiatan militer yang dalam hal ini dijelaskan sebagai bagian dari Komponen Utama harus didukung oleh Komponen Cadangan dan Komponen Pendukung sesuai dengan yang tertulis dalam Doktrin Pertahanan Negara.

Selain kegiatan yang berhubungan dengan kebencanaan, masalah yang sangat serius dan utama yang dihadapi bangsa saat ini adalah masuknya ideologi asing yang mengkhianati Pancasila dan munculnya banyak kasus Radikalisme Terorisme menuju ekstrimisme.

Berdasarkan riset Global Terorism Index (GTI) menunjukkan bahwa Indonesia berada pada peringkat 37 dari 162 negara di Dunia dengan skor 4.63 pada tahun 2020 sebagai negara yang terdampak terorisme (Knoema, 2020, “Global Terorism Index" diakses dari knoema.com). Laporan ini menunjukkan bahwa tingkat terorisme di Indonesia cukup tinggi.

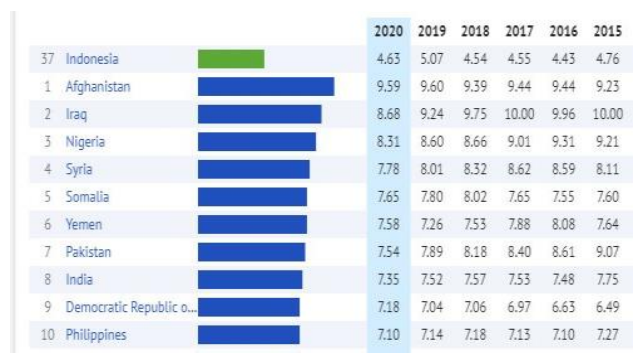

Gambar 1. Global Terorism Index, 2020

Dikutip dari jdih.bnpt.go.id, Survei Alara Research Centre menemukan ada sebagian milenial atau generasi kelahiran akhir 1980-an, dan awal 1990-an, setuju pada konsep khilafah sebagai bentuk negara. survey dilakukan terhadap 4.200 milenial yang terdiri dari 1.800 mahasiswa dan 2.400 pelajar SMA di Indonesia. Kondisi ini menunjukkan bahwa generasi produktif Indonesia meskipun mayoritas milenial memilih NKRI ada sebanyak 17,8 persen mahasiswa dan 18,4 persen pelajar yang setuju khilafah sebagai bentuk negara ideal. Perlu ada penanganan khusus mengingat komposisi penduduk terbesar di usia produktif sebayak 25,87 \% untuk Generasi Milenial (databoks.katadata.co.id).

Masalah-masalah seperti ancaman radikalisme disebabkan banyak hal khususnya yang terjadi di Indonesia. Persoalan tersebut dapat berupa: kekurangpahaman terhadapa ideologi Pancasila dan budaya sadar konstitusi sebagai pedoman hidup berbangsa, bernegara dan bermasyarakat; kekurangan pemahaman gerakan-gerakan radikalisme yang tumbuh di masyarakat; kekurangoahaman cara dan strategi mendeteksi sejak dini; dan ketidakmampuan mencegah munculnya gerakan radikalisme melalui penanaman Pancasila dan budaya sadar konstitusi yang tumbuh di masyarakat (Satriawan, 2019).

Adapun beberapa penelitian terdahulu terkait Komponen Cadangan adalah sebagai berikut: (1) Muradi, 2012, Organisasi Komponen Cadangan Matra Darat, sebagai makalah pengantar pada rapat kajian organisasi komponen cadangan matra darat, Direktorat Jenderal Potensi Pertahanan. Makalah ini menguraikan bahwa urgensi komponen cadangan mengacu pada perkembangan ancaman kedepannya yang tidak sekadar ancaman militeristik dan juga pembangunan wajib bertahap untuk pertahanan negara. adapun Komponen Cadangan dibentuk oleh organisasi Matra Darat yang akan bekerja sama dengan pemerintah daerah dalam perekrutan komponen cadangan (Muradi, 2012). Makalah ini tidak membahas secara kompleks mengenai ancaman-ancaman nonmiliter terhadap urgennsi pembentukan komponen cadangan dan kurikulum pelatihan selain kemampuan dasar militer. Penelitian selanjutnya (2) oleh Endro Tri Susdarwono, 2020, Analisis terhadap Wajib Militer dan Relevansinya dengan Rancangan Undang-undang Komponen Cadangan. Jurnal peneltian Khatulistiwa Review menelaah mengenai perbadaningan ruu Komponen Cadangan dan UU Wajib Militer, bahwa adanya UU PSDN dan RUU Komponen Cadangan telah menggeser makna wajib militer yang bersifat wajib dengan pelatihan kemampuan dasar kemiliteran secara sukarela bagi warga sipil yang lulus tahap seleksi menjadi komponen cadangan (Susdarwono, 2020). Penelitian ini juga belum membahas urgensi pembentukan 
Komponen Cadangan terhadap ancaman non militer dan kurikulum selain kemiliteran.

Penelitian selanjutnya (3) berjudul "Membangun Komponen Cadangan Berbasis Kemampuan Bela Negara sebagai kekuatan Pertahanan Indonesia Menghadapi Ancaman Nir-Militer", oleh Raden Mas Jerry Indrawan dan Efriza, 2018. Hasil penelitian ini menjelaskan mengenai kemampuan bela negara sebagai kurikulum wajib komponen cadnagan sebagai pendukung kekuatan komponen utama dalam menangkal ancaman nir militer (Indrawan, Efriza, 2018).

Penelitian terdahulu secara umum belum membahas topik sebagaimana yang penulis lakukan yakni bagaimana urgensi pembentukan komponen cadangan dalam upaya menghadapi ancaman nonmiliter khususnya terorisme dan radikalisme. Belum ada penelitian yang membahas strategi kurikulum pendidikan atau pendampingan selaian pelatihan dasar militer khususnya dalam menghadapi ancaman terorisme dan radikalisme ala sipil. Lantas, apa hubungan antara urgensi pembentukan Komponen Cadangan dengan Radikalisme-terorisme di Indonesia? Dalam jurnal ini akan dibahas mengenai urgensi pembentukan komponen cadangan sebagai salah satu alternative solusi dalam penanggulangan ancaman radikalisme-terorisme di Indoenesia.

\section{HASIL DAN PEMBAHASAN}

Perekrutan Komponen Cadangan (Komcad) yang berasal dari orang muda Indonesia di kalangan sipil dimulai sejak masa jabatan Menteri Pertahanan Prabowo Subianto. Sampai saat ini dengan adanya pandemic Covid-19 juga masih dipertanyakan urgensi apa yang menjadikan program besar ini untuk dijalankan. Dikutip dari laman daring artikel liputan6.com, bahwa ada empat badan hukum dan tiga individu yang tergabung dama Tim Advokasi untuk Reformasi Sektor Keamanan yakni Imparsial, KontraS, Yayasan Kebajikan Publik Jakarta, PBHI, serta ketiga individu yakni Ikhsan Yosarie, Gustika Fardani Jusuf, dan Leon Alvinda

\section{METODE}

Penelitian ini menggunakan pendekatan kualitatif dengan metode studi kasus. Pendekatan kualitatif dimaksudkan untuk memahami masalah-masalah manusia dalam konteks sosial dengan menciptakan gambaran yang menyeluruh dan kompleks yang disajikan, melaporkan pandangan terperinci dari para sumber informasi tanpa intervensi dari peneliti. Studi kasus penelitian ini adalah program Perekrutan Komponen Cadangan pada tahun 2020-2021 di Indonesia.

Objek penelitian dalam jurnal ilmiah ini berasal dari kajian pustaka atau literature baik yang berasal dari media daring maupun media cetak mengenai Komponen Cadangan sebagai program dan kebijakan Kementerian Pertahanan dan Radikalisme sebagai satu masalah utama dalam kurun waktu 10 tahun kebelakang. Adapun literatur primer adalah Undang-undang Nomor 23 tahun 2019 tentang Pengelolaan Sumber Daya Nasional, website komcad.kemhan.go.id, dan sumber sekunder lainnya berupa artikel dan penjelasan tertulis lainnya.

Penelitian ini menggunakan teknik pengumpulan data berupa studi pustaka. Studi pustaka sangat penting dalam proses penelitian ini sebagai kajian teoritis dalam upaya peningkatan kualitas dan aktualitas secara akademis penelitian ini. Sumber pustaka yang digunakan dapat berupa jurnal, penelitian, buku, artikel, e-book, dan laman media daring yang diakses melalui internet.

Putra. Beberapa pihak tersebut mengajukan uji materiil UU PSDN yang melibtkan rekrutmen Komponen Cadangan di tengah kebutuhan penanganan Pandemi Covid-19 saat ini (Nanda Perdana Putra, 2021, "ProKontra Rekrutmen Komponen Cadangan, UU PSDN Digugat ke MK") Mengingat anggaran yang tidak sedikit baik alokasi anggaran belanja Kementerian Pertahanan khususnya dalam usaha penyelenggaraan program Komponen Cadangan ini.

Secara umum dapat dimengerti bahwa Komponen Cadangan adalah kekuatan untuk memperkuat kemampuan Komponen Utama jika ada ancaman baik ancaman militer maupun nonmiliter bersama TNI sebagai Komponen Utama. Berlatar belakang hal itu, Komponen Cadangan (Komcad) harus 
dilatih dan dipersiapkan dengan baik untuk pertahanan negara.

Berdasarkan UU Nomor 23 Tahun 2019 Tentang Pengelolaan Sumber Daya Nasional untuk Pertahanan Negara, Komponen Cadangan adalah Sumber Daya Nasional yang telah disiapkan untuk dikerahkan melalui mobilisasi guna memperbesar dan memperkuat kekuatan dan kemampuan Komponen Utama. Dijelaskan juga bahwa Mobilisasi yang dimaksud adalah tindakan pengerahan dan penggunaan secara serentak Sumber Daya Nasional serta Sarana dan Prasarana Nasional yang telah dipersiapkan dan dibina sebagai komponen kekuatan Pertahanan Negara untuk digunakan secara tepat, terpadu,, dan terarah bagi penanggulangan setiap ancaman, baik dari luar negeri maupun dari dalam negeri yang membahayakan persatuan dan kesatuan bangsa serta kelangsungan hidup bangsa dan Negara Kesatuan Republik Indonesia. (Undang-undang Nomor 23 Tahun 2019).

Dari penjelasan di atas dijelaskan bahwa pembentukan Komponen Cadangan memang sudah diatur sesuai amanat undangundang. Sebagai bagian dari Sumber Daya Nasional untuk Pertahanan Negara, Komponen Utama (TNI) sudah ada tetapi untuk Komcad masih berupa peraturan dalam Undang-undang. Karena itu sebagai salah satu upaya pemerintah dalam mewujudkan pertahanan semesta, Komponen Cadangan dibentuk dan dimulai perekrutannya sejak tahun 2020 sebagai salah satu program Menteri Pertahanan.

Berdasarkan informasi perekrutan Komcad pada website komcad.kemhan.go.id, setiap warga negara yang berusia 18-35 tahun dengan latar belakang apa saja dapat mendaftarkan diri menjadi anggota Komcad. Berbeda dengan kebijakan wajib militer seperti yang ada di negara lain, Komcad sifatnya sukarela dan siap sedia apabila suatu waktu negara mendapat ancaman.

Pada tahun 2021, perekrutan Komponen Cadangan dibuka untuk matra darat dengan kuota sekitar 2.500 peserta (Yahya, 2021). Pada tahun 2020, Kementerian Pertahanan merekrut sekitar 25.000 Komcad (pikiranrakyat.com). Kegiatan pelatihan dilakukan di beberapa lokasi seperti Kodam Jaya Jakarta, Kodam II Siliwangi, Kodam IV Diponegoro dan
Kodam V Brawijaya, selama total 3 bulan (Yahya, 2021). Pelatihan Dasar Militer ini merupakan juga rangkaian yang nantinya peserta dapat dinyatakan sebagai anggotaKomcad.. Setelah pelatihan, anggota Komcad akan dikembalikan ke instansi dan pekerjaannya masing-masing dan akan diadakan penyegaran pelatihan selama 12 hari setiap tahunnya.

\section{Bela Negara dalam Program Komponen Cadangan}

Tentu tidak mudah untuk menjadi anggota Komcad. Ada banyak hal yang harus dimiliki oleh calon anggota meskipun program ini dilakukan atas dasar sukarela sebagai wujud pertahanan negara. Menjadi Komcad juga merupakan salah satu wujud bela negara.

Dasar hukum Bela Negara yang tertulis pada Undang Undang Dasar Tahun 1945, Pasal 27 ayat (3) mengamanatkan bahwa "Setiap warga negara berhak dan wajib ikut serta dalam upaya pembelaan negara" dan pada pasal 30 ayat (1) mengamanatkan bahwa "Tiap-tiap warga negara berhak ikut serta dalam usaha pertahanan dan keamanan negara" (kemhan.go.id). Dihubungankan dengan sistem pertahanan Indonesia yang bersifat semesta maka kesemestaan itu yang berarti keikutsertaan seluruh elemen bangsa terutama masyarakat yang berkewajiban ikut serta dalam upaya pembelaan negara demi keamanan negara

Lanjut lagi kepada pembahasan yang tertuang dalam UU RI No.3 Tahun 2002 tentang Pertanan Negara pada Pasal 9 ayat (1) mengamanatkan bahwa, "Setiap warga negara berhak dan wajib ikut serta dalam upaya bela negara yang diwujudkan dalam penyelenggaraan pertahanan negara", dan pada ayat (2) dijelaskan mengenai bentuk penyelenggaraan seperti melalui: pendidikan kewarganegaraan; pelatihan dasar kemiliteran secara wajib; pengabdian sebagai prajurit Tentara Nasional Indonesia secara sukarela atau secara wajib; dan pengabdian sesuai dengan profesi. Berdasarkan dasar hukum ini, kegiatan perekrutan Komcad dan masyarakat yang mengikuti dan menjadi anggota Komcad sudah melaksanakan kewajibannya dalam upaya bela negara. Hal ini juga didukung amanah UU No.23 Tahun 2019 Pasal 6 ayat 
(3c) bahwa mendaftar sebagai calon anggota Komponen Cadangan adalah Hak Warga Negara dalam usaha Bela Negara.

Namun, terdaftar sebagai anggota Komcad secara sukarela dan mengikuti pelatihan dasar kemiliteran, tidak serta merta menghentikan tugas dalam upaya bela negara. Ada beberapa hal yang perlu diperhatikan sebagai kewajiban pasca pelatihan, nilai-nilai, aturan dan sanksi yang harus diperhatikan. Wujud bela negara dapat dilakukan secara fisik dan non-fisik. Secara fisik dengan cara mengangkat senjata dan non-fisik dengan upaya mempertahankan NKRI degan cara meningkatkan kesadaran berbangsa dan bernegara, menanamkan kecinta terhadap tanah air serta berperan aktif dalam memajukan bangsa dan negara (Agung, 2016). Dalam UU No, 23 Tahun 2019, kewajiban dari Komponen Cadangan adalah: setia dan taat pada Pancasila, undang-undang dasar Negara Republik Indonesia Tahun 1945, dan Negara Kesatuan Republik Indonesia; menjaga persatuan dan kesatuan bangsa; menaati ketentuan peraturan perundang-undangan; melaksanakan tugas dengan penuh pengabidan, kejujuran, kesadaran, dan tanggung jawab; menunjukkan integritas dan keteladanan dalam sikap, perilaku, ucapan, dan tindakan kepada setiap orang; mengikuti pelatihan penyegaran; dan memenuhi panggilan mobilisasi. Pada poin pertama dan kedua jelas sekali dinyatakan bahwa anggota Komponen Cadangan harus memiliki integritas yang kuat kepada bangsa agar layak menjadi pendukung kekuatan utama untuk menangkal baik ancaman militer dan ancaman nonmiliter.

Pelatihan dasar militer yang menjadi ketentuan dalam pembentukan komponen cadangan dimaksudkan agar para anggota memahami apa yang harus dilakukan jika terjadi ancaman seperti perang atau bencana alam. Selain itu, pelatihan dasar militer dilakukan dengan tujuan untuk melatih dasar kemampuan keprajuritan, disiplin, dan bertahan. Dilansir dari Menwa UI, bahwa pelatihan atau pendidikan dasar militer (diksarmil) terdiri dari pelatihan fisik, 3C (Cover, Concealment, dan Camouflage), Bela Diri Militer, Cargo Net, Konstruksi Bivak, Teknik Tempur Dasar, Pengantar Senjata Ringan, Survival, Combat Livesaving, dan Navigasi Darat (menwa.ui.ac.id). Kemampuan ini merupakan kemampuan yang sangat dibutuhkan oleh komponen cadangan yang berfungsi untuk mendukung komponen utama yakni TNI. Kecakapan lewat diksarmil ini tentunya tidak sepenuhnya menjadikan anggota Komcad sepenuhnya sempurna, misalnya dalam menangkal ancaman ideologi. Dibutuhkan kemampuan lain untuk mengatasi ancaman ini.

\section{Komponen Cadangan, strategi menangkal Radikalisme}

Komponen Cadangan berbeda dengan Wajib Militer seperti yang terjadi di beberapa negara lain seperti Korea Selatan. Korea Selatan memiliki program wajib militer karena status gencata senjata dengan Korea Utara, sehingga dengan status belum damai menjadikan kedua negara selalu dalam status siap perang. Komponen Cadangan bukan wajib militer karena merupakan suatu program sukarela (tidak wajib) yang diamanatkan UU No.23 tahun 2019 Tentang Pengelolaan Sumber Daya Nasional untuk Pertahanan Negara (ppid.kemhan.go.id).

Pada tahun 2020 ditargetkan sekitar 25000 pemuda Indonesia usia 18-35 tahun berhak menjadi anggota Komcad dengan syarat lulus seleksi, dengan kata lain sudah ada 25000 pemuda yang dilatih integritasnya sesuai nilai-nilai bela negara dan setia pada Pancasila. Tahun berikutnya direkrut 2500 calon komponen cadangan, dan akan terjadi seterusnya. Langkah ini merupakan langkah strategis yang bisa dilakukan pemerintah untuk menjaga kualitas pemuda Indonesia untuk tetap nasionalis dan berintegritas.

Program sukarela ini menjadi sangat menarik karena tanpa paksaan dan merupakan kesadaran dari dalam diri untuk ikut serta dalam mendukung komponen utama dalam menghadapi segala jenis ancaman. Tentunya, kesadaran ini tidak hanya dapat dilakukan jika bergabung menjadi komponen cadangan. Ada banyak karya dan kegiatan lain untuk ikut serta dalam usaha pertahanan negara seperti tidak ikut arus radikalisme, terorisme, separatisme, dan pengaruh ideologi selain Pancasila.

Salah satu ormas yang dibubarkan di Indonesia adalah HTI (Hizbut Tahrir) yang 
dibubarkan pemerintah karena dianggap ancaman akan mengubah ideologi Pancasila (tirto.id). Menurut Riset Setara Institut dikutip dari tirto.id bahwa ada 10 perguruan tinggi negeri di Indonesia terpapar paham Islam radikalisme yang dibawa oleh kelompok salafi-wahabi, tarbiyah, dan tahririyah. Dan di masa pandemi saat ini, BNPT menghimbau agar masyarakat waspada dalam propaganda terorisme dan radikalisme melalui media daring karena akan lebih mudah mendoktrin generasi muda untuk mendukung ideologi terorisme (bnpt.go.id).

Untuk memahami Pancasila secara komprehensif dan bagaimana pengimplementasiannya tidak beres hanya dalam kegiatan seperti pelatihan dasar militer. Dalam persyaratan perekrutan memang diwajibkan untuk beriman dan bertakwa kepada Tuhan Yang Maha Esa dan setia pada Negara Kesatuan Republik Indonesia yang berdasarkan Pancasila dan Undang-undang Dasar 1945, tetapi untuk menjadikan komponen cadangan yang berkualitas harus memiliki pondasi yang kuat tentang Pancasila dan Wawasan Kebangsaan.

Setelah 3 bulan mengikuti pelatihan dasar kemiliteran , komponen cadangan akan dikembalikan ke instansi masing-masing. Seorang yang juga memiliki identitas sebagai anggot komcad harus memiliki kualitas unggul dibandingkan yang belum bergabung dengan Komcad. Komcad harus memberi pengaruh baik terutama dalam praktik bela negara dan nasionalisme di lingkungan kerjanya karena status Komcad selalu harus dipertanggungjawabkan.

Khususnya dalam penanggulangan radikalisme teorisme di kalangan masyarakat sipil, Komcad harus siap untuk menghentikan penyebaran radikalisme. Misalnya, Komcad berasal dari kalangan mahasiswa. Sebagaimana banyak data yang melaporkan mengenai penyebaran pahampaham ideologi asing anti Pancasila yang menyebabkan intoleransi di tengah komunitas perguruan tinggi, komcad harus berusaha untuk menindaklanjuti kegiatan tempat distribusi paham radikalisme. Apabila Komcad berasal dari kalangan pekerja maka harus berani ikut campur tangan ketika melihat rekan kerja menunjukkan sikap anti Pancasila.
Mengingat kewajiban yang harus diemban anggota Komcad yang sudah mengucapkan sumpah/janji Komponen Cadangan yang dilakukan menurut agama dan kepercayaan kepada Tuhan Yang Maha Esa, merupakan program yang efektif salah satunya untuk menanggulangi ancaman radikalisme-terorisme di Indonesia. Berasal dari kalangan masyarakat sipil dan kembali ke lingkungan masyarakat harus dilihat sebagai strategi yang sangat tepat sasaran. Salah satu pendekatan yang bisa dilakukan oleh Komcad yang telah kembali ke kegiatan sebelumnya adalah dengan soft-approaching ke masyarakat. Kegiatan dapat berupa mengajak pemuda lainnya untuk ikut program Komcad. Kegiatan lain tentunya harus actual dan beradapatasi dengan perkembangan zaman karena sasarannya adalah orang muda Indonesia. Kampanye perdamaian, nilai-nilai Pancasila, dan tidak menyebarkan berita bohong di media sosial menjadi salah satu bentuk soft-approaching. Melakukan riset terkait bela negara dan Pancasila di lingkungan pendidikan, mengarahkan teman di lingkungan untuk tidak sembarangan mengikuti komunitas yang mengatasnamakan agama, dan lain sebagainya.

Untuk mendapatkan kualitas Komcad yang tetap berkontribusi sesuai nilai Pancasila diperlukan juga kurikulum dan pendampingan yang sesuai selama dalam masa pendidikan Komcad. Kegiatan tidak perlu monolog seperti kelas, dapat dikreasikan seperti melakukan proyek penelitian atau pengadian yang hasilnya dapat secara nyata diimplementasikan di tengah masyarakat.

Perumusan kegiatan ini dapat dilakukan lewat kolaborasi dengan Direktorat Jenderal Potensi Pertahanan, Direktorat Bela Negara, Universitas yang mengusung semangat Bela Negara seperti UPN Veteran dan Universitas Pertahanan, lembaga masyarakat seperti LSM dan instansi terkait lainya seperti BNPT. Pendidikan untuk calon anggota Komponen Cadangan harus komprehensif dan tidak setengah-setengah, mengingat banyaknya jenis ancaman mengikuti perkembangan lingkungan strategis.

Selain anggota Komcad yang akan dijaga kesetiaannya pada Pancasila dan NKRI, mereka juga bisa menjadi agen 
perubahan bagi masyarakat umum terutama generasi muda dalam menghadapi ancaman ideologis seperti radikalisme dan terorisme. Kondisi ancaman yang selalu ada menjadikan pembentukan Komponen Cadangan sangat dibutuhkan.

Diadakan perekrutan setiap tahun dengan jumlah rekrutan yang tidak sedikit dan berasal dari masyarakat sipil Indonesia dan dari segala jenis profesi dan mengikuti pelatihan dasar militer selama tiga bulan, merupakan satu langkah strategis untuk melindungi dan mengawal para pemuda Indonesia untuk terhindar dari ancaman seperti radikalisme, terorisme, separatisme, dan ancaman ideologis lainnya, karena mereka dilatih menjadi individu yang nasionalis sesuai nilai bela negara dan Pancasila.

\section{SIMPULAN}

Pembentukan Komponen Cadangan (Komcad) sebagai pendukung kekuatan Komponen Utama yaitu TNI merupakan kebijakan yang tepat dilakukan mengingat sudah ada UU No.23 Tahun 2019 yang mengatur mengenai Sumber Daya Pertahanan. Perekrutan yang diambil dari kalangan masyarakat usia 18-35 tahun lintas profesi juga sebagai wujud sistem pertahanan yang bersifat semesta yang artinya usaha pertahanan dan keamanan nasional adalah hak dan kewajiban seluruh warga negara salah satunya bergabung menjadi Komponen Cadangan yang terlatih. Komponen Cadangan akan ditugaskan untuk menanggulangi ancaman baik ancaman militer, nonmiliter, maupun ancaman hibrida yang selalu mengikuti perkembangan lingkungan strategis.

Salah satu ancaman yang dalam kurun waktu 10 tahun kebelakang dan masih menjadi fokus baik pemerintah dan masyarakat adalah fenomena penyeberan paham radikalisme-terorisme, ekstrimisme, dan munculnya ideologi-ideologi antiPancasila. Ancaman ini harus disikapi karena mengancam integrasi nasional juga ideologi bangsa yang menjadi dasar dan falsafah hidup bangsa Indonesia. Karena itu, adanya Komponen Cadangan yang nantinya juga akan berkarya dan kembali ke masyarakat sebagaimana profesi dan pekerjaannya, perlu dibekali pengetahuan, pemahaman yang komprehensif tentang persoalan radikalisme terutama di kalangan orang muda usia produktif. Sudah sangat bagus dengan pembekalan pendidikan dasar militer dan kebencanaan, tetapi akan lebih efisien jika para Komcad yang bergabung dengan masyarakat juga dijadikan sebagai agen yang mampu mengatasi persoalan ideologis seperti radikalisme. Sebagai Komcad mereka harus dapat menginspirasi orang muda lainnya baik di instansi mereka bekerja atau di lingkungan tempat mereka tinggal sesuai kreativitas dan fleksibilitas perkembangan zaman seperti pemanfaatan teknologi.

Penelitian ini bertujuan untuk memberikan solusi kepada pembuat kebijakan khususnya penyusunan kurikulum pendampingan komponen cadangan bahwa perlu adanya keterampilan secara sosial kultural yag diajarkan dan diterapkan berupa kurikulum pendidikan. Adapun strategi yang dapat dilakukan adalah dengan memberi pemahaman yang baik mengenai Pancasila, UUD 1945, wawasan kebangsaan, dan keterampilan menyebarkan nilai-nilai perdamaian dengan memanfaatkan instrument yang ada seperti media sosial dan lainnya. Keterampilan ini cocok dimiliki oleh kekuatan komponen cadangan mengingat perekrutan berasal dari kalangan sipil, lintas golongan, yang nantinya setelah pendidikan akan dikembalikan ke masyarakat.

Oleh karena itu, adanya pembentukan dan perekrutan Komponen Cadangan setiap tahunnya juga meningkatkan jumlah orang muda yang dikawal mentalitas kebangsaan, wawasan kebangsaan, kemampuan militer dan kebencanaan, dan kemampuan untuk menangkal segala bentuk ancaman ideologis khususnya radikalisme. Semakin banyak anak muda setiap tahunnya ikut serta dalam program perekrutan Komponen Cadangan, semakin banyak pula orang muda lainnya yang terinspirasi untuk menjaga nasionalisme lewat pengamalan nilai-nilai Pancasila dan Bela Negara. 


\section{DAFTAR PUSTAKA}

Umra, Sri Indriyani. (2019). Penerapan Konsep Bela Negara, Nasionalisme Atau Militerisasi Warga Negara. Lex Renaissance, 1 (4). Pp. 164-178

Satriawan, Iwan \& Muhammad Nur Islam. (2019). Pencegahan Gerakan Radikalisme melalui Penanaman Ideologi Pancasila dan Budaya Sadar Konstitutsi Berbasis Komunitas. Jurnal Surya Masyarakat. 1 (2), pp. 99-110

Malik, Abd, Januari (2020). Teropong Potensi Radikalisme 2020. Majalah Jalan Damai Pusat Media Damai BNPT, pp. 14

Indrawan, Raden Mas Jerry, Efriza. (2018). Membangun Komponen Cadangan Berbasis Kemampuan Bela Negara Sebagai kekuatan Pertahanan Indonesia Menghadapi Ancaman Nir-militer. Jurnal Pertahanan dan bela Negara. 8(2). Pp. 21-40

Susdarwono, Endri Tri. (2020). Analisis Terhadap Wajib Militer dan Relevansinya dengan Rancangan Undang-Undang Komponen Cadangan. Jurnal Khatulistiwa. 1 (2), Oktober 2020. Pp. 130-147

Muradi, (2012). Organisasi Komponen Cadangan Matra Darat. Makalah. Direktorat Jenderall Potensi Pertahanan. Kementerian Pertahanan

Kementerian Pertahanan Republik Indonesia. (2014). Doktrin Pertahanan Negara. Jakarta: Kementerian Pertahanan Republik Indonesia.

Undang-Undang Republik Indonesia Nomor 23 Tahun 2019 tentang Pengelolaan Sumber Daya Nasional untuk Pertahanan Negara.

Agung, I Gusti Bagus Wirya. (2016). Pendidikan Kewarganegaraan Bela Negara. Penelitian Pendidikan Pembangunan Karakter Bangsa, Bali, Universitas Udayana

Knoema. (tanpa tahun). Global Terrorism Index. Diakses 24 Agustus 2021. Diakses dari https://knoema.com/atlas/topics/WorldRankings/World-Rankings/Globalterrorism-index?baseRegion=ID

Jayani, Dwi Handya. (2021). Proporsi Populasi Generasi $Z$ dan Milenial Terbesar di Indonesia. Diakses 24 Agustus 2021. Diakses

dari https://databoks.katadata.co.id/datapublis h/2021/05/24/proporsi-populasigenerasi-z-dan-milenial-terbesar-diindonesia

Mulyana, Cahya. (2021). Urgensi Komcad Kemhan Perlu Diperjelas. Diakses 24 Agustus 2021, diakses dari https://mediaindonesia.com/politik-danhukum/378299/urgensi-komcadkemenhan-perlu-diperjelas

Yahya, Achmad Nasrudin. (2021). Kemenhan Buka Perekrutan Komponen Cadangan 2-7 Juni 2021, Ini Lokasi Pendaftarannya. Diakses 25 Agustus 2021, diakses dari https://nasional.kompas.com/read/2021/ 05/24/08521101/kemenhan-bukaperekrutan-komponen-cadangan-2-7juni-2021-ini-lokasi

Pikiran Rakyat Com. (2020). Mulai 1-29 Agustus 2020, Menhan Buka Pendaftaran Komcad untuk Umum dengan 8 Syarat Wajib. Diakses 25 Agustus 2021, diakses dari https://www.pikiranrakyat.com/nasional/pr-01664172/mulai1-29-agustus-2020-menhan-bukapendaftaran-komcad-untuk-umumdengan-8-persyaratan-wajib?page $=3$

Kementerian Pertahanan Indonesia. (2017). Sejarah Bela Negara. diakses pada 28 Agustus 2021, diakses dari https://www.kemhan.go.id/belanegara/se jarah-bela-negara

Menwa UI. (tanpa tahun). Pendidikan Dasar Militer (Diksarmil). Diakses pada 28 Agustus 2021, diakses dari https://menwa.ui.ac.id/what-wedo/training/pendidikan-dasar-militerdiksarmil/

Abdi, Alfian Putra. (2019). Setara Institute Sebut 10 Kampus Terpapar Paham Radikalisme. Diakses pada 28 Agustus 2021, diakses dari https://tirto.id/setarainstitute-sebut-10-kampus-terpaparpaham-radikalisme-d9nh

Khadafi, Ahmad. (2017). Sejarah Kemunculan HTI hingga Akhirnya Dibubarkan. Diakses pada 28 Agustus 2021, diakses dari https://tirto.id/sejarah-kemunculanhti-hingga-akhirnya-dibubarkan-coiC

Putra, Nanda Perdana. (2021). Pro-Kontra Rekrutmen Komponen Caadangan, UU PSDN Digugat ke MK. Diakses pada 12 
Jurnal Pancasila dan Bela Negara Vol.1 No.2, September 2021, hal.49-.58.

E-ISSN:2775-5886

Desember 2021. Diakses dari https://www.liputan6.com/news/read/45 70759/pro-kontra-rekrutmenkomponen-cadangan-uu-psdn-digugatke-mk

BNPT. (2021). BNPT Waspadai Penyebaran Paham Radikalisme dan Terorisme di Internet Selama Masa Pandemi Covid19. Diakses pada 28 Agustus 2021, diakses dari https://www.bnpt.go.id/bnpt-waspadaipenyebaran-paham-radikalisme-danterorisme-di-internet-selama-masapandemi-covid-19

\section{UCAPAN TERIMA KASIH}

Penulis mengucap syukur kepada Tuhan Yang Maha Esa karena penulis dapat menyelesaikan jurnal ini. Penulis juga berterimakasih kepada pihak-pihak yang sudah membantu proses penulisan lewat diskusi terkait permasalahan yang diangkat.

\section{TENTANG PENULIS}

Yesika Theresia Sinaga lahir dan besar di Sumatera Utara dan menempuh pendidikan sarjana di Filsafat Universitas Gadjah Mada dan melanjutkan studi master di Universitas Pertahanan program studi Damai dan Resolusi Konflik. 